\title{
Seasonal Changes in Iodine Metabolism
}

\author{
1. Iodine Content of Cows' Milk
}

\author{
G. D. BROADHEAD,* B.SC., PH.D. ; I. B. PEARSON,* M.B., CH.B. ; G. M. WILSON, $\dagger$ M.D., D.SC., F.R.C.P.
}

Brit. med. F., 1965, 1, 343-348

Regional differences in the prevalence of goitre in Britain were recognized during the early part of the last century (Inglis, 1838) and there is evidence that these still persist (Kilpatrick, Milne, Rushbrooke, Wilson, and Wilson, 1963). The importance of iodine deficiency in the pathogenesis of goitre has been established beyond reasonable doubt, though it is now clear that other factors may also be important in the development of thyroid enlargement. In the past considerable attention has been paid to the concentration of iodine in water-supplies (Murray, Ryle, Simpson, and Wilson, 1948) but in Britain this usually lies between 1 and $4 \mu \mathrm{g}$./litre. Consequently the human requirement of iodine for health, often placed at about $100 \mu \mathrm{g}$. a day, must be met largely from the diet. The food richest in iodine is undoubtedly marine fish (Chilean Iodine Educational Bureau, 1952), but this is only an occasional item in the diet. Another foodstuff relatively rich in iodine is cows' milk, and this is important, particularly in childhood, as it is consumed daily in large amounts. During the course of investigations into the pathogenesis of non-toxic goitre a large seasonal fluctuation was observed in the iodine content of milk which entirely overshadowed any regional differences. The extent and cause of this fluctuation in iodine concentration were accordingly investigated further.

\section{Methods}

\section{Determination of Iodine in Milk}

This method was developed from that described by Acland (1957) for the measurement of serum-protein-bound iodine. AnalaR reagent grade chemicals and deionized water were used in all the determinations.

Reagents.-Sodium carbonate solution:-Anhydrous sodium carbonate (102 g.) was dissolved in 1,000 ml. of water ; carrier-free ${ }^{131}$ I was added $(50 \mu \mathrm{c}$.$) . Ceric ammonium sulphate solution:-$ Ceric ammonium sulphate, low in rare earths $(8.15 \mathrm{~g}$.), was dissolved in water; concentrated sulphuric acid ( $80 \mathrm{ml}$.) was added, and the volume made up to $1,000 \mathrm{ml}$. with water. Arsenious acid solution : -Arsenious oxide (3.15 g.) was dissolved in water containing sodium hydroxide $(1.65 \mathrm{~g}$.$) ; concentrated sulphuric acid (70 \mathrm{ml}$.) was added, and the volume made up to $1,000 \mathrm{ml}$. with water. Hydrochloric acid solution:-Concentrated hydrochloric acid (63 ml.) was added to water and then diluted to $1,000 \mathrm{ml}$. Standard iodine solution:-Potassium iodide $(0.13 \mathrm{~g}$.) was dissolved in 1,000 $\mathrm{ml}$. of water ; $1 \mathrm{ml}$. of this solution was diluted to $100 \mathrm{ml}$. and the standard solution containing iodine $0.02 \mu \mathrm{g} . / \mathrm{ml}$. was made by diluting $5 \mathrm{ml}$. of the final solution to $250 \mathrm{ml}$.

Measurement of Iodine in Liquid Milk.-Twelve hard-glass tubes $(10$ by $1.5 \mathrm{~cm}$.) were taken and $2 \mathrm{ml}$. of sodium carbonate solution containing ${ }^{131} \mathrm{I}$ was put into each. One was left blank, and into the next was placed a standard urine sample $(1 \mathrm{ml}$.), which was used as a reference standard in all iodine determinations made in the department. These provided evidence of the reproducibility of the results. Five milk samples were taken and $3 \mathrm{ml}$. was placed in each of two test-tubes. In one of each pair of test-tubes con-

* Wellcome Research Fellow, Department of Pharmacology and Therapeutics, University of Sheffield. + Professor, Department of Pharmacology and Therapeutics, University
of Sheffield. taining milk $2 \mathrm{ml}$. of iodine solution $(0.02 \mu \mathrm{g} . / \mathrm{ml}$.) was placed. There were therefore one blank, one standard urine, five milks, and five milks with added iodine. These tubes were dried overnight at $100^{\circ} \mathrm{C}$. in an oven and then placed in a furnace at $600^{\circ} \mathrm{C}$. for 30 minutes. After cooling, hydrochloric acid $(3 \mathrm{ml}$.) was added to each tube, which was shaken and then water $(5 \mathrm{ml}$.) added. These tubes were centrifuged at 3,000 r.p.m. for five minutes, and $3 \mathrm{ml}$. of the supernatant was transferred to colorimeter tubes. The colorimeter tubes and tubes containing solutions of ceric ammonium sulphate and arsenious acid were placed in a water-bath at $37^{\circ} \mathrm{C}$. and left for 10 minutes. Arsenious acid $(1 \mathrm{ml}$.) was added to the colorimeter tubes, which were left a further 30 minutes. Ceric ammonium sulphate $(1 \mathrm{ml}$.) was added to each tube at intervals of a minute and the transmission of each sample was measured exactly 12 minutes later in a Unican S.P. 600 spectrophotometer set at a wavelength of $415 \mathrm{~m} \mu$. Recovery of ${ }^{181} \mathrm{I}$ was determined by counting $1-\mathrm{ml}$. samples taken from the colorimeter tubes and comparing them with the stock sodium-carbonate/ ${ }^{121} \mathrm{I}$ solution ( $1 \mathrm{ml}$.).

Calculation of Iodine Content of Milk.-Let the spectrophotometer readings be represented as follows:

$$
\theta_{0}=\text { blank, } \theta_{\mathbf{x}}=\text { milk, } \theta_{\mathbf{y}}=\text { milk }+0.04 \mu \mathrm{g} \text {. iodine. }
$$

The concentration of iodine in samples $\mathrm{x}$ and $\mathrm{y}$ is proportional to $\log \theta_{0}-\log \theta_{x}$ and $\log \theta_{0}-\log \theta_{y}$, but these expressions must be corrected for the loss of iodine as determined by the ${ }^{181}$ I recovery. Accordingly let $R_{\mathbf{x}}$ and $\mathbf{R}_{\mathbf{y}}$ represent the proportionate recoveries. Then the calibration slope

$$
S=\frac{\mathbf{R}_{\mathbf{y}}\left(\log \theta_{\mathbf{o}}-\log \theta_{\mathbf{y}}\right)-\mathbf{R}_{\mathbf{x}}\left(\log \theta_{\mathbf{o}}-\log \theta_{\mathbf{x}}\right)}{0.04}
$$

and the concentration of the iodine in the milk $=\frac{\mathbf{R}_{\mathbf{x}}\left(\log \theta_{\mathbf{o}}-\log \theta_{\mathbf{x}}\right)}{S}$

Addition of Known Amounts of ${ }^{127} I$ to Milk Samples.-In a series of experiments known amounts of iodine were added to milks of low-iodine content. The samples were reanalysed and the recovery of added iodine calculated. The results were as follows:

\begin{tabular}{c|c|c}
\hline No. of Samples & $\begin{array}{c}\text { Iodine Added to } \\
\text { 3 ml. of Milk ( } \mu \text { g.) }\end{array}$ & $\begin{array}{c}\text { \% Iodine Recovered } \\
\pm \text { S.D. }\end{array}$ \\
\hline 6 & $0 \cdot 15$ & $88 \pm 6$ \\
6 & 0.30 & $99 \pm 4$ \\
6 & 0.60 & $98 \pm 2$ \\
6 & $1 \cdot 20$ & $91 \pm 7$ \\
\hline
\end{tabular}

Recovery of ${ }^{101} I$. - The average recovery of ${ }^{191} I$ in the 264 samples of milk analysed was $59.3 \pm 5.4 \%$ (S.D.).

Variation in Standard Urine.-The average concentration of iodine found in 43 determinations carried out in conjunction with the milk samples was $0.141 \pm 0.006 \mu \mathrm{g} . / \mathrm{ml}$. (S.D.).

Variation in Iodine Content of Stored Milk.-As the liquid milk from Scotland was analysed later than the Sheffield milk the effect of delaying the analysis of local milk was investigated. In repeated analyses made of milk kept at room temperature for up to six days no loss of iodine was detected.

Measurement of Iodine Content of Dried Milk.-Samples of dried milk (about $1 \mathrm{~g}$.) were weighed and mixed with deionized water (5 ml.) and allowed to stand for 24 hours. The samples were centrifuged and the supernatant was decanted into hard glass testtubes. The determinations were continued as for liquid milks. Precipitation of the protein in these solutions by zinc hydroxide showed that less than $5 \%$ of the iodine was protein-bound. 
Measurement of Iodine Content of Cattle Food.-The foodstuffs were ground and $10-\mathrm{mg}$. samples handled in the same way as the liquid milk.

\section{Measurement of Thiocyanate in Liquid Milk}

The method was adapted from that described by Bowler (1944) for determinations in serum. Milk (10 ml.) was placed in a centrifuge tube and $5 \%$ trichloracetic acid solution $(5 \mathrm{ml}$.) added. The tube was centrifuged at 1,500 r.p.m., and $5 \mathrm{ml}$. of the supernatant was transferred to a colorimeter tube and ferric nitrate solution ( $5 \mathrm{ml}$.) added. After standing in the dark for 5 minutes the thiocyanate content was measured in an E.E.L. colorimeter and compared with standard thiocyanate solutions.

\section{Measurement of Calcium in Liquid Milk}

A method based on that described by Powell (1953) was followed. Milk (1 ml.) was mixed with saturated $\mathrm{NaOH}$ solution $\left(1 \mathrm{ml}\right.$.) and saturated $\mathrm{KNO}_{3}$ solution $(1 \mathrm{ml}$.) and dried overnight. The organic material was destroyed by heating to $600^{\circ} \mathrm{C}$. in a furnace. Concentrated $\mathrm{HCl}(3 \mathrm{ml}$.) was added and allowed to stand for 30 minutes and then mixed with water ( $3 \mathrm{ml}$.$) . Duplicate samples (1 \mathrm{ml}$.) were placed in conical centrifuge tubes and 3 drops of bromothymol-blue indicator added and then concentrated ammonium hydroxide till the blue endpoint was reached. Ammonium-oxalate/oxalic-acid solution $(5 \mathrm{ml}$.) was added, and after standing for 30 minutes the tubes were centrifuged for 10 minutes at 1,500 r.p.m. The liquid was decanted and the residue dissolved in perchloric acid $(10 \mathrm{ml}$.) and the calcium estimated in an E.E.L. flame photometer by comparison with standard solutions.

\section{Results}

Iodine Content of Liquid Milk.-Analyses have been made of milk drawn from three sources at weekly intervals during 1963. The first is a farm situated at an altitude of about $1,000 \mathrm{ft}$. $(300 \mathrm{~m}$.) on the west side of Sheffield on the edge of the Derbyshire moorland. The second is bulked milk provided by a large dairy in Sheffield ; this milk comes from many farms in Yorkshire and Derbyshire. The third is bulked milk from a dairy in Edinburgh supplied by farms in southern Scotland. The same seasonal trend in the iodine content of the milk is evident in all the samples (Table I). The concentration is greatest in the first four months of the year. A steep fall occurs towards the end of April and continues throughout May; the lowest levels are found during August. A slow climb becomes evident in October and thereafter the concentration rises steadily throughout the remainder of the year. The iodine content of

TABLE I.-Monthly Iodine Contents of Liquid Milks in 1963 ( $\mu \mathrm{g.} /$

\begin{tabular}{|c|c|c|c|c|c|c|c|c|c|c|c|c|c|}
\hline \multicolumn{14}{|c|}{$100 \mathrm{ml})}$. \\
\hline Source of Milk & & $\mathrm{J}$. & F. & M. & A. & M. & J. & J. & A. & S. & O. & N. & D. \\
\hline rm & .. & 14 & 17 & 16 & 21 & 3 & 4 & 4 & 1 & 2 & - & 3 & 7 \\
\hline $\begin{array}{l}\text { Bulk supply, } \\
\text { Sheffield .. }\end{array}$ & & 14 & 15 & 15 & 11 & 5 & 2 & 2 & 2 & 2 & 2 & 6 & 9 \\
\hline $\begin{array}{l}\text { 3ulk supply, } \\
\text { Edinburgh }\end{array}$ & .. & 7 & 10 & 9 & 5 & 1 & 2 & 2 & 1 & 2 & 4 & 2 & 6 \\
\hline
\end{tabular}

TABLE II.-Iodine, Thiocyanate, and Calcium Content of Bulk Liquid Milk in Sheffield, 1959-60

\begin{tabular}{|c|c|c|c|c|c|c|c|c|c|c|c|c|c|}
\hline & \multicolumn{4}{|c|}{1959} & \multicolumn{9}{|c|}{1960} \\
\hline & s. & o. & N. & D. & J. & F. & M. & A. & M. & J. & J. & A. & s. \\
\hline $\begin{array}{l}\text { Iodine ( } \mu \\
100 \text { l. } \\
\text { Thiocyyan }\end{array}$ & 4 & 4 & 6 & 4 & 8 & 11 & 10 & 17 & 2 & 3 & 1 & 1 & 8 \\
\hline (mg./10 & 0.72 & 0.83 & $0.79 \mid$ & $0.73 \mid$ & 0.73 & $0 \cdot 67$ & 0.63 & 0.56 & 0.76 & 0.66 & 0.76 & 0.87 & 0.80 \\
\hline (mg./100 ml.) & 167 & 195 & 164 & 182 & 196 & 182 & 208 & 223 & 184 & 196 & 176 & 162 & 138 \\
\hline
\end{tabular}

the Scottish milk during the winter months is less than that of the English milks. Similar, less complete investigations have been made of the iodine content of milk in previous years from 1959 onwards. The same seasonal change is evident (Table II and Chart).

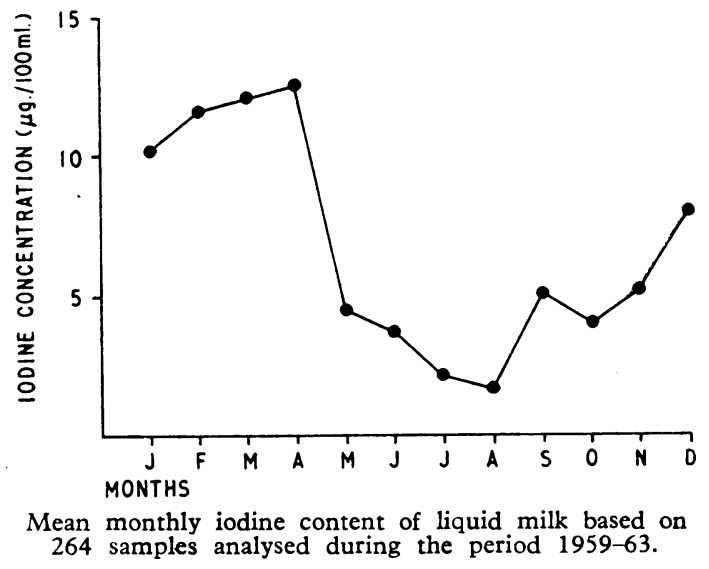

Iodine Content of Dried Milk.-Analyses were made of samples of dried milk obtained from two drying plants, one in north Yorkshire and the other in Fife, Scotland. The former produced full-cream dried milk and the latter skimmed dried milk. In both the same seasonal variation was again apparent (Table III).

TABLE III.-Iodine Content of Whole Bulk-dried Milk from Yorkshire and Skim Bulk-dried Milk from Scotland ( $\mu$ g. Iodide per $100 \mathrm{~g}$. Dried Milk)

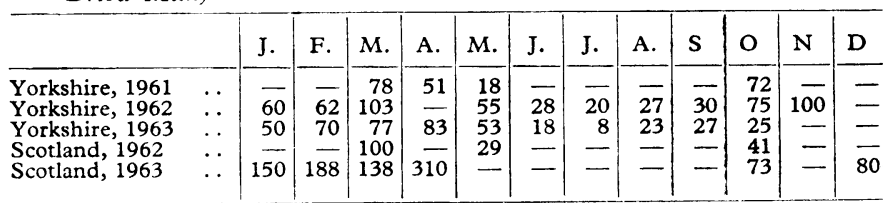

Thiocyanate and Calcium in Liquid Milk.-During the course of the measurements of iodine the concentrations of thiocyanate and calcium have been studied (Table II). A small seasonal change is evident in both. The amount of thiocyanate is smallest during the spring months, when the concentration of iodine is greatest, and rises later as the iodine falls. The content of calcium follows that of iodine.

Grazing and Feeding of Milking-cows.-A detailed account was maintained of the management of the cows on the Sheffield farm. The following represents the general pattern over the last four years, though minor variations may be introduced, depending on the weather and the yield of milk. From November to April the cows are kept indoors and each cow receives daily, ground barley $12 \mathrm{lb}$. (5.5 kg.), hay $12 \mathrm{lb}$. (5.5 kg.), and "dairy cake" $4 \mathrm{lb}$. (1.8 kg.) for each gallon (4.5 1.) of milk yielded after the first. One brick of mineral lick weighing about $1 \mathrm{~kg}$. is provided to cover the six-month period. Three different brands of dairy cake were used. They consist principally of cereals and oil seeds, and a general mineral supplement which includes iodine is added by the manufacturers. In May the cows are gradually allowed out on the pastures, and over a period of a few weeks the feeding is modified. The barley and hay are reduced to 4 to $6 \mathrm{lb}$. $(1.8$ to $2.7 \mathrm{~kg}$.) a day. The dairy cake is discontinued, but the cows are given "grazing cake" at about $4 \mathrm{lb}$. (1.8 kg.) per cow during milking. The grazing cake consists principally of cereals and does not contain any iodine supplement. Calcined magnesite is given as a prophylaxis against tetany; this contains a negligible quantity of iodine. In October a similar transition period occurs in reverse as the cows are brought back under cover, but the tetany prophylaxis is omitted. During June to September the cows are completely on pasture and each receives daily barley about 
$6 \mathrm{lb} .(2.7 \mathrm{~kg}$.) and grazing cake about $4 \mathrm{lb} .(1.8 \mathrm{~kg}$.). No mineral lick is provided during this period. The iodine content of these various constituents of the cows' diet is shown in Table IV. The three brands of dairy cake differed considerably in their content of iodine, but were usually fed together. The proportions in which they were given is not known.

\begin{tabular}{|c|c|c|c|}
\hline & & & $\mu \mathrm{g} . / 100 \mathrm{~g}$. \\
\hline $\begin{array}{l}\text { Hay “ “A } \\
\text { Brand "A" grazing cake } \\
\text { Ground Barley } \\
\text { Flake Barley } \\
\text { Brand "A" } \\
\text { Brand "B" dairy cake } \\
\text { Brand "B" dairy cake } \\
\text { Salt-lick "dairy cake } \\
\text {.. }\end{array}$ & $\begin{array}{l}\ldots \\
\because \\
\because \\
\because \\
\cdots\end{array}$ & $\begin{array}{l}\because \\
\because \\
\therefore \\
\because \\
\therefore\end{array}$ & $\begin{array}{c}\text { None detected } \\
\text { " } " ~ \\
\text { " } \\
885 \\
380 \\
120 \\
910\end{array}$ \\
\hline
\end{tabular}

\section{Discussion}

Many analyses of the iodine content of cows' milk have been published and the results have been summarized by the Chilean Iodine Educational Bureau (1952). The earlier estimations usually gave results lower than those reported here, but they were made before radioiodine was used as a routine check on loss during analysis. Wide variations in the iodine content of milk have been reported in the past, but it is now difficult to discern to what extent they may have been due to the analytical procedure, geographical differences, or seasonal changes.

A seasonal variation has been noted in some previous reports. In a Medical Research Council (1936) survey the mean values obtained in summer and winter milk respectively were in Somerset (a goitre area) 0.8 and $3.2 \mu \mathrm{g} . / 100 \mathrm{ml}$. and in Suffolk (a non-goitre area) 0.8 and $3.8 \mu \mathrm{g} . / 100 \mathrm{ml}$. In the winter some exceptionally high values ranging up to $16.2 \mu \mathrm{g} . / 100 \mathrm{ml}$. were noted in samples from some districts. No explanation was offered for these differences. Vilkki (1956) described in detail changes in the iodine content of Finnish milk between winter and summer. The consistently higher values in winter were attributed to supplementary iodine given to the cows. In Oxfordshire Hughes, Rodgers, and Wilson (1959) reported a mean concentration of $6 \mu \mathrm{g} . / 100 \mathrm{ml}$. in winter and $2 \mu \mathrm{g} . / 100$ $\mathrm{ml}$. in summer, and this was related to the iodine supplement given to the cows. It is clear that in any comparison of dietary intake of iodine between goitrous and non-goitrous districts the present large seasonal variation must be taken into account.
A seasonal variation in the concentration of thiocyanate in milk has previously been reported by Boulangé (1959), who noted a rise during the summer months when the cows went out on to pasture. The seasonal change in the concentration of both thiocyanate and calcium are proportionately much smaller than that occurring in iodine.

The variation in the iodine content of milk is due almost entirely to the large but variable supplement contained in the dairy cake given during the winter. It occurs in both liquid and dried milk. In the latter, which may be used for infantfeeding, the seasonal fluctuation could make a considerable difference in the iodine intake if a baby happened to be fed largely on either the summer or winter product. There is no official policy governing the amount of iodine added to the dairy cake, but this supplement has been included for some years in the winter foodstuffs and has recently been increased in amount by at least one manufacturer. It is clearly preferable that the supplement should be standardized and continued throughout the summer. This could probably best be done by including it in the grazing cake which the cows consume while being milked during the summer months. In this way it should be possible to ensure that the iodine content of milk did not fall below $15 \mu \mathrm{g} . / 100 \mathrm{ml}$. If this were done it would be a strong safeguard against the development of iodine deficiency.

\section{Summary}

The iodine content of samples of liquid and dried milk from Yorkshire and Scotland has been measured during the years 1959-63.

A definite seasonal fluctuation was apparent. The concentration of iodine in liquid milk rose during the early months of the year to a maximum of about $20 \mu \mathrm{g} . / 100 \mathrm{ml}$. in March and April. Thereafter it declined to a minimum value of about $1 \mu \mathrm{g} . / 100 \mathrm{ml}$. in August and September. It rose slowly during the last three months of the year. A similar variation occurred in dried milk.

The iodine content of the foodstuffs supplied to cows throughout the year on a Sheffield farm was measured in relation to the changes in the milk. The large seasonal change was due to the feeding during the winter months of cattle cake to which iodine had been added in large amounts. It is suggested that the supplement given to the cows in winter should be retained throughout the whole year.

\section{Fluctuation in Urinary Iodine Excretion}

The main pathway of iodine excretion in man is through the kidneys (Riggs, 1952). If the subject is in metabolic balance urinary iodine excretion provides an indication of iodine intake, and this method has commonly been employed in demonstrating iodine deficiency in goitrous regions (Stanbury, 1960). Reliance has usually been placed on a single 24-hour collection of urine, and until recently little attention has been paid to the inherent variability of such a measurement.

In the present study we have investigated fluctuations in urine iodine excretion and the effect of changes in iodine intake. In particular the influence of milk has been studied, as a large seasonal variation has been detected in its content of iodine.

\section{Methods}

The method for determining the concentration of iodine in urine was essentially similar to that described for milk (Broadhead et al., 1965). The same reagents and procedure were used, and the only difference was that $1 \mathrm{ml}$. of urine was used in place of $3 \mathrm{ml}$. of milk. In a few measurements where the urinary iodine concentration was above $0.1 \mu \mathrm{g} . / \mathrm{ml}$. either the sample was diluted or a smaller quantity was taken. Analyses of fish followed the method previously described for cattle food. In all the measurements the recovery of ${ }^{131} \mathrm{I}$ was measured and a sample of the same standard urine was included as previously described.

Addition of Known Amounts of ${ }^{127} I$ to Urine Samples.-In a series of experiments known amounts of iodine were added to five specimens of urine of different iodine content. The samples were then re-analysed, with the following results:

\begin{tabular}{|c|c|c|c|c|c|c|c|c|}
\hline \multirow{2}{*}{\multicolumn{4}{|c|}{$\begin{array}{l}\text { Iodine Added } \\
(\mu \mathrm{g} . / \mathrm{ml} .)\end{array}$}} & \multicolumn{5}{|c|}{ Iodine Concentration in Urines ( $\mu \mathrm{g} . / \mathrm{ml}$.) } \\
\hline & & & & \multirow{2}{*}{$\begin{array}{c}\text { A } \\
0.027 \\
0.082 \\
0.118\end{array}$} & \multirow{2}{*}{$\begin{array}{c}\text { B } \\
0.035 \\
0.094 \\
0.126\end{array}$} & \multirow{2}{*}{$\begin{array}{c}C \\
0.042 \\
0.101 \\
0.135\end{array}$} & \multirow{2}{*}{ 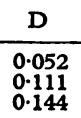 } & \multirow{2}{*}{ 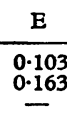 } \\
\hline $\begin{array}{l}0 \\
0.06 \\
0.09\end{array}$ & $\because$ & $\because$. & $\ddot{a}$ & & & & & \\
\hline
\end{tabular}


Recovery of ${ }^{131} I$. - The average recovery of ${ }^{131} \mathrm{I}$ in the 1,040 samples of urine analysed was $93 \pm 3 \%$ (S.D.). This is considerably higher than that achieved in the milk analyses, and is due to the much lower residue after ashing.

Variation in Standard Urine.-The average concentration of iodine found in 260 measurements of the standard urine carried out in conjunction with the unknown urines was $0.140 \pm$ $0.011 \mu \mathrm{g} . / \mathrm{ml}$. (S.D.).

\section{Results}

Daily Urinary Iodine Excretion.-The daily urinary iodine excretion from 8 a.m. to 8 a.m. was measured throughout the week in 29 healthy subjects. The observations were made during October 1961 to February 1962. They ate an unrestricted diet following their normal routine and did not use iodized salt during either the previous month or the week of the collections. Each subject showed a wide variation from day to day (Table I). The mean coefficient of variation was $37.7 \%$ and the range was from $16.7 \%$ to $84.2 \%$. A record was kept of the food consumed at each meal, but it was not possible to identify the cause of many of the fluctuations. The effect of fish and milk is described below. The results were examined in relation to each day of the week but no consistent change was evident (Table II). The mean daily excretion of iodine correlated closely with the weight of the subject (see Chart).

Effect of Iodized Salt.-In four subjects the collections of urine over a week were repeated, while iodized salt (0.002$0.003 \% \mathrm{KI}$ ) was used at home both for cooking and for addition at meals. The change to iodized salt was made at least four weeks before the collections were begun. In each case there was a rise in urinary iodine excretion ranging from 27 to $200 \mu \mathrm{g}$./day (Table I).

Addition of Known Iodine Supplements.-In five subjects $500 \mu \mathrm{g}$. of iodine in the form of a solution of potassium iodide was taken at breakfast at the beginning of a 24-hour collection. The urinary iodine excretion on the previous day and on the

TABLE I. - Mean Daily Excretion of Iodine in Urine ( $\mu$ g./24 hrs. \pm S.D.)

\begin{tabular}{|c|c|c|c|c|c|}
\hline Subject & Sex & Age & Wt. (kg.) & $\begin{array}{c}\text { Non-iodized } \\
\text { Salt }\end{array}$ & $\begin{array}{l}\text { Iodized } \\
\text { Salt }\end{array}$ \\
\hline $\begin{array}{r}1 \\
2 \\
3 \\
4 \\
5 \\
6 \\
7 \\
8 \\
9 \\
10 \\
11 \\
12 \\
13 \\
14 \\
15 \\
16 \\
17 \\
18 \\
19 \\
20 \\
21 \\
22 \\
23 \\
24 \\
25 \\
26 \\
27 \\
28 \\
29\end{array}$ & $\begin{array}{l}M \\
M \\
M \\
M \\
M \\
M \\
M \\
M \\
M \\
M \\
M \\
F \\
F \\
F \\
F \\
F \\
F \\
F \\
F \\
F \\
F \\
F \\
F \\
F \\
F \\
F \\
F \\
F \\
F \\
F\end{array}$ & $\begin{array}{l}39 \\
49 \\
18 \\
16 \\
23 \\
30 \\
45 \\
23 \\
30 \\
36 \\
46 \\
18 \\
27 \\
20 \\
48 \\
27 \\
16 \\
20 \\
36 \\
17 \\
17 \\
17 \\
58 \\
15 \\
19 \\
50 \\
29 \\
36 \\
26\end{array}$ & $\begin{array}{l}50 \\
57 \\
65 \\
68 \\
76 \\
80 \\
80 \\
82 \\
83 \\
85 \\
91 \\
43 \\
48 \\
48 \\
48 \\
49 \\
51 \\
51 \\
52 \\
55 \\
55 \\
57 \\
57 \\
58 \\
63 \\
64 \\
66 \\
70 \\
83\end{array}$ & 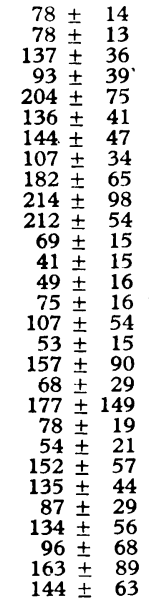 & $\begin{array}{l}120 \pm 34 \\
344 \pm 130\end{array}$ \\
\hline
\end{tabular}

TABLB II.-Variation in Iodine Excretion During Week in Normal Subjects ( $\mu \mathrm{g} . / 24$ hrs. $\pm S . D$.

\begin{tabular}{|c|c|c|c|c|}
\hline & & & $\begin{array}{l}\text { Non-iodized Salt } \\
29 \text { Subjects }\end{array}$ & $\begin{array}{l}\text { Iodized Salt } \\
4 \text { Subjects }\end{array}$ \\
\hline $\begin{array}{l}\text { Monday .. } \\
\text { Tuesday . } \\
\text { Wednesday } \\
\text { Thursday } \\
\text { Friday .. } \\
\text { Saturday . } \\
\text { Sunday .. }\end{array}$ & $\begin{array}{l}\cdots \\
\cdots \\
\cdots \\
\cdots \\
\cdots\end{array}$ & $\begin{array}{l}\ldots \\
\cdots \\
\cdots \\
\cdots \\
\cdots\end{array}$ & $\begin{array}{r}84 \pm 40 \\
127 \pm 85 \\
107 \pm 60 \\
121 \pm 62 \\
133 \pm 82 \\
138 \pm 84 \\
114 \pm 76\end{array}$ & 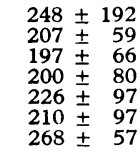 \\
\hline
\end{tabular}

succeeding two days is shown in Table III. The mean increase in urinary iodine excretion on the day of the supplement was $304 \mu \mathrm{g}$., representing $61 \%$ of the dose. The values had returned to the normal range on the second day after the supplement had been taken.

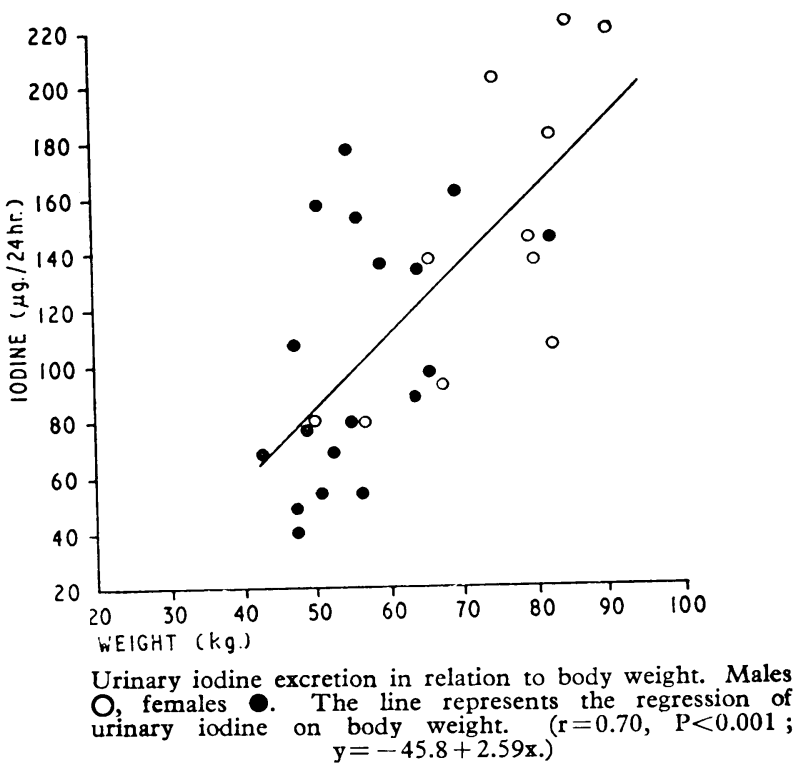

TABLE III.-Effect of $500 \mu \mathrm{g}$. of Iodine Taken with Breakfast on Second Day on Urinary Iodine Excretion ( $\mu \mathrm{g} . / 24 \mathrm{hr}$.)

\begin{tabular}{|c|c|c|c|c|c|c|}
\hline \multirow{2}{*}{ Subject } & \multirow{2}{*}{ Sex } & \multirow{2}{*}{ Age } & \multirow{2}{*}{ Wt. (kg.) } & \multicolumn{3}{|c|}{ Day } \\
\hline & & & & 1 & 2 & 3 \\
\hline $\begin{array}{r}6 \\
7 \\
9 \\
28 \\
30\end{array}$ & $\begin{array}{c}\mathrm{M} \\
\mathrm{M} \\
\mathrm{M} \\
\mathrm{F} \\
\mathrm{F}\end{array}$ & $\begin{array}{l}30 \\
45 \\
30 \\
36 \\
21\end{array}$ & $\begin{array}{l}80 \\
80 \\
83 \\
70 \\
70\end{array}$ & $\begin{array}{r}66 \\
125 \\
244 \\
183 \\
126\end{array}$ & $\begin{array}{l}368 \\
424 \\
546 \\
515 \\
413\end{array}$ & $\begin{array}{r}85 \\
111 \\
272 \\
208 \\
122\end{array}$ \\
\hline Mean & & & & 149 & 453 & 160 \\
\hline
\end{tabular}

Effect of Fish in Diet.-A study of the daily diet of the subjects in Table I had shown that some of the day-to-day changes in iodine excretion might be related to the consumption of sea fish. This often, but not invariably, caused a definite increase. Analyses of different varieties of fish purchased in Sheffield showed a wide range in content of iodine (Table IV). In a further series of experiments six subjects consumed a meal of $180 \mathrm{~g}$. of haddock (Table V). Samples of the fish were analysed for iodine content; the mean was $130 \mu \mathrm{g} / 100 \mathrm{~g}$. The fish in the meal thus provided $234 \mu \mathrm{g}$. of iodine. No other fish was taken for two days before and during the experiment, but the intake of milk was not restricted. In three of the six subjects the excretion of iodine in the urine was greatest on the day when the fish was eaten. No explanation was found for the occasional high levels observed on the other days.

TaBle IV.-Iodine Content in $\mu g . / 100 \mathrm{~g}$. of Fresh Fish (Wet Weight)

\begin{tabular}{|c|c|c|c|c|c|}
\hline \multicolumn{3}{|c|}{ Fish } & No. of Samples & Mean & Range \\
\hline $\begin{array}{l}\text { Cod } \\
\text { Haddock } \\
\text { Plaice }\end{array}$ & & $\begin{array}{l}\cdots \\
\cdots\end{array}$ & $\begin{array}{l}4 \\
5 \\
2\end{array}$ & $\begin{array}{r}225 \\
122 \\
60\end{array}$ & $\begin{array}{r}129-386 \\
93-174 \\
54-65\end{array}$ \\
\hline
\end{tabular}

TABLE V.-Effect of Fish. A Meal of Haddock $(180 \mathrm{~g}$.$) was Consumed$ TaBLE Midday on Tuesday by Each Subject (Iodine Excretion $\mu \mathrm{g} . / 24 \mathrm{hr}$.)

\begin{tabular}{|c|c|c|c|c|c|c|c|c|c|}
\hline $\begin{array}{l}\text { Subject } \\
\text { Age } \quad . \\
\text { Sex } \quad \ldots \\
\text { Wt. (kg.) }\end{array}$ & $\begin{array}{l}\ldots \\
\cdots \\
\cdots\end{array}$ & $\begin{array}{l}. \\
\because \\
\cdots\end{array}$ & $\begin{array}{c}6 \\
30 \\
M \\
80\end{array}$ & $\begin{array}{l}20 \\
17 \\
\mathrm{~F} \\
55\end{array}$ & $\begin{array}{l}31 \\
17 \\
F \\
52\end{array}$ & $\begin{array}{l}32 \\
17 \\
\mathrm{~F} \\
56\end{array}$ & $\begin{array}{l}33 \\
18 \\
F \\
61\end{array}$ & $\begin{array}{l}34 \\
17 \\
F \\
54\end{array}$ & Mean \\
\hline $\begin{array}{l}\text { Monday } \\
\text { Tuesday } \\
\text { Wednesday } \\
\text { Thursday }\end{array}$ & $\begin{array}{l}\ldots \\
\because \\
\cdots\end{array}$ & $\begin{array}{l}\ldots \\
\ldots \\
\ldots\end{array}$ & $\begin{array}{r}189 \\
179 \\
66 \\
100\end{array}$ & $\begin{array}{r}53 \\
142 \\
97 \\
93\end{array}$ & $\begin{array}{r}53 \\
140 \\
39 \\
44\end{array}$ & $\begin{array}{l}144 \\
168 \\
180 \\
102\end{array}$ & $\begin{array}{r}84 \\
244 \\
120 \\
93\end{array}$ & $\begin{array}{r}121 \\
141 \\
93 \\
143\end{array}$ & $\begin{array}{r}107 \\
169 \\
99 \\
96\end{array}$ \\
\hline
\end{tabular}


TABLE VI.-Average Excretion of Urinary Iodine in Three Subjects During 1963 ( $\mu \mathrm{g} . / 24 \mathrm{hr}$. )

\begin{tabular}{|c|c|c|c|c|c|c|c|c|c|c|c|c|c|c|c|}
\hline Subject & Sex & Age & Wt. (kg.) & $\mathrm{J}$ & $\mathrm{F}$ & M & A & $M$ & $\mathrm{~J}$ & $\mathrm{~J}$ & A & $\mathbf{S}$ & O & $\mathbf{N}$ & D \\
\hline $\begin{array}{r}7 \\
9 \\
21\end{array}$ & $\begin{array}{c}\mathbf{M} \\
\mathbf{F}\end{array}$ & $\begin{array}{l}45 \\
30 \\
17\end{array}$ & $\begin{array}{l}80 \\
83 \\
55\end{array}$ & $\begin{array}{r}262 \\
118 \\
65\end{array}$ & $\begin{array}{r}202 \\
178 \\
86\end{array}$ & $\begin{array}{r}211 \\
141 \\
63\end{array}$ & $\begin{array}{r}186 \\
135 \\
48\end{array}$ & $\begin{array}{r}261 \\
136 \\
57\end{array}$ & $\begin{array}{r}250 \\
82 \\
48\end{array}$ & $\begin{array}{r}180 \\
91 \\
31\end{array}$ & $\overline{32}$ & $\begin{array}{r}136 \\
99 \\
18\end{array}$ & $\begin{array}{r}140 \\
87 \\
\end{array}$ & $\begin{array}{l}157 \\
177 \\
-\end{array}$ & $\begin{array}{l}187 \\
158\end{array}$ \\
\hline
\end{tabular}

Seasonal Variation in Urinary Iodine Excretion.-In three subjects urine was collected during all the days that they were in Sheffield in 1962. Pooled weekly collections were analysed and the mean daily excretion of iodine was calculated for each month (Table VI). A normal diet was consumed without any restrictions. A definite decrease in iodine excretion was apparent during the period June to October, when the values were approximately half those recorded during the winter months. In Subject 21 the iodine excretion fell to a very low level but no goitre was apparent. This seasonal change was further studied in 15 subjects who collected urine for a week in July or August 1963 and again for a week in February or March 1964. Most of them also collected for a second week on each occasion, when they entirely excluded milk from their diet (Table VII). During all these observations no fish was consumed. While milk was being taken the mean urinary iodine excretion was $129 \mu \mathrm{g} . / 24 \mathrm{hr}$. in February-March, but fell to $76 \mu \mathrm{g} . / 24 \mathrm{hr}$. in July-August ( $59 \%$ of the winter value). When milk was excluded from the diet there was a large decrease in urinary iodine excretion in the winter period but a much smaller change in the summer. On a milk-free diet the mean urinary iodine excretion in winter and in summer showed little difference.

TABLB VII.-Effect of Season and Milk on Urinary Iodine. ( $\mathrm{gg} / 24 \mathrm{hr}$.

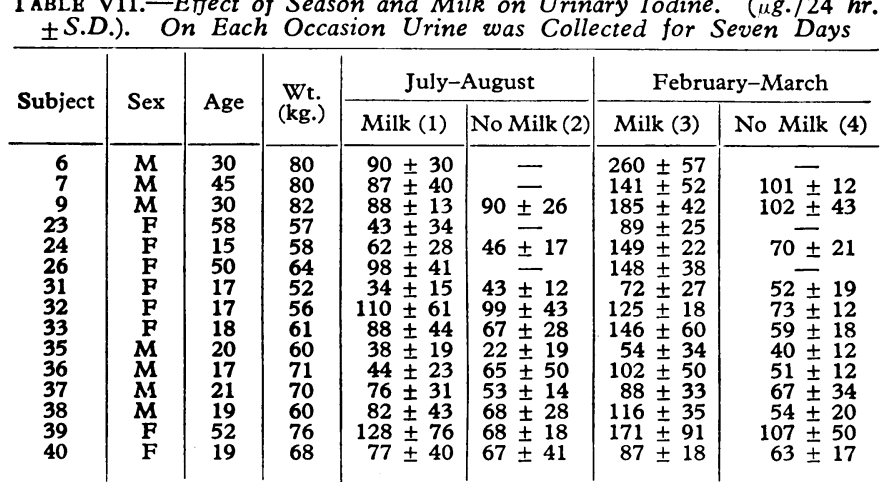

\begin{tabular}{c|c|c|c}
\hline & $\begin{array}{c}\text { Mean } \\
\text { Differences }\end{array}$ & $\mathrm{t}$ & $\mathrm{P}$ \\
\cline { 2 - 3 }$(1-2)$ & +12.6 & 0.1997 & $0.9-0.8$ \\
$(3-4)$ & +49.7 & 6.4046 & $<0.001$ \\
$(3-1)$ & +52.6 & 4.9159 & $<0.001$ \\
$(4-2)$ & +4.5 & 0.2899 & $0.8-0.7$
\end{tabular}

\section{Discussion}

Under carefully controlled conditions in a metabolic unit of a hospital urinary iodine excretion may show little change over several days (Vought, London, Lutwak, and Dublin, 1963). In people eating unrestricted diets under ordinary living conditions a large day-to-day variation is apparent. Under these conditions there is wide range in the dietary intake of iodine (Vought and London, 1964). It is impossible to identify all the sources of variation. Sea fish is widely recognized as rich in iodine (Chilean Iodine Educational Bureau, 1952), and some increases followed its consumption, though the iodine content of even the same type of fish is extremely variable. Eggs are another rich source of iodine (Vilkki, 1956 ; Vought and London, 1964), and enter into many prepared foodstuffs. Hence wide day-to-day fluctuations are to be anticipated. However, even in an area where severe dietary iodine deficiency exists similar wide fluctuations in excretion are evident. Thus in Mendoza the mean daily excretion of iodine in the urine $(23.6 \mu \mathrm{g} . / 24 \mathrm{hr}$.) was much lower than in Sheffield but the variability was remarkably similar. The mean coefficient of variation was $39 \%$ and the range 13 to $79 \%$ (Stanbury, Brownell, Riggs, Perinetti, Itoiz, and Castillo, 1954).

A seasonal change in urinary iodine excretion was evident, and this was due to the previously described decrease in iodine concentration in milk occurring during the summer months (Broadhead et al., 1965). Between winter and summer urinary iodine excretion fell by about $40 \%$. Urinary iodine excretion is closely related to plasma inorganic iodine (Wayne, Kontras, and Alexander, 1964) and in any comparisons of goitrous and healthy subjects full account must be taken of this large seasonal fluctuation.

The change in the urinary excretion of iodine from winter to summer confirms the importance of milk as a source of iodine in the diet. In the survey of the food consumption of families in Britain in 1961 the mean weekly intake of liquid milk was 4.9 pints $(2.74$ 1.) per person (Annual Report of National Food Survey Committee, 1963). In Sheffield during March this would yield about $450 \mu \mathrm{g}$. of iodine in a week, but during August and September this would drop to about 35 $\mu \mathrm{g}$. For comparison, in this survey the weekly consumption of fish was $5.69 \mathrm{oz}$. (159 g.) ; of this about one-tenth is fish such as canned salmon, which has a much lower iodine content than solely marine fish. The iodine content of fish varies widely, as our estimates have shown, and similar findings have been reported previously (Vilkki, 1956; Wayne et al., 1964). The Chilean Iodine Educational Bureau (1952) suggests a mean figure of $832 \mu \mathrm{g} . / \mathrm{kg}$. If this is accepted the ration of fish in the week would provide about $135 \mu \mathrm{g}$. of iodine. Even if fish particularly rich in iodine-for example, 2,000 $\mu \mathrm{g} . / \mathrm{kg}$.-was eaten, the weekly supply from this source $(318 \mu \mathrm{g}$.) would be less than that provided by milk in winter. Furthermore, the consumption of milk is increasing year by year while that of fish is steadily declining (Annual Report of National Food Survey Committee, 1963). Milk in winter is thus a regular important daily source of iodine in contrast to the occasional consumption of fish, and is probably particularly significant in childhood. The evidence from the measurements of urinary excretion suggests that the rich supply of iodine in the milk in winter constitutes the main safeguard against the development of iodine deficiency.

\section{Summary}

The daily excretion of iodine in the urine was measured over a week in 29 healthy subjects on unrestricted diets. Considerable variation was evident from day to day and little reliance could be placed on a single 24 -hour collection. The mean urinary iodine excretion correlated closely with the weight of the subject.

Approximately $60 \%$ of a single supplement of $500 \mu \mathrm{g}$. of iodine taken by mouth was recovered in the urine.

A meal of sea fish might increase urinary iodine excretion, but the effect was variable owing to wide differences in the iodine content of fish.

A seasonal change in excretion of iodine was apparent; the amount excreted declined during the summer, so that in the period July to September it was not quite half that encountered during the winter. This decrease was due to the fall in the concentration of iodine in milk during the summer months 
and demonstrated the importance of milk as a source of iodine in the diet.

We are grateful to Dr. J. S. Milne for arranging for the delivery of milk from Edinburgh and to Mrs. D. Bingham for supply of milk and for assistance in keeping records of the feeding of cows. Miss G. Gillott gave valuable technical help. The work was supported by grants from the Endowment Fund of the United Sheffield Hospitals, the Wellcome Trust, and the Medical Research Council.

\section{REFERENCES}

Acland, J. D. (1957). Biochem. f., 66, 177.

Annual Report of National Food Survey Committee (1963). Domestic Food Consumption and Expenditure, 1961. H.M.S.O., London.

Boulangé, M. (1959). C.R. Soc. Biol. (Paris), 153, 2019.

Bowler, R. G. (1944). Biochem. F., 38, 385.
Chilean Iodine Educational Bureau (1952). Iodine Content of Foods. London.

Hughes, D. E., Rodgers, K., and Wilson, D. C. (1959). Brit. med. F., 1 , 280.

Inglis, J. (1838). Treatise on English Bronchocele, With a Few Remarks on the Use of Iodine and Its Compounds. Longmans, London.

Kilpatrick, R., Milne, J. S., Rushbrooke, M., Wilson, E. S. B., and Wilson, G. M. (1963). Brit. med. F., 1, 29.

Medical Research Council (1936). Spec. Rep. Ser. med. Res. Coun. (Lond.), No. 217.

Murray, M. M., Ryle, J. A., Simpson, B. W., and Wilson, D. C. (1948). Memor. Med. Res. Coun. (Lond.), No. 18.

Powell, F. J. N. (1953). 7. clin. Path., 6, 286.

Riggs, D. S. (1952). Pharmacol. Rev., 4, 284.

Stanbury, J. B. (1960). Wld Hith Org. Monogr. Ser., No. 44, p. 261 . Brownell, G. L., Riggs, D. S., Perinetti, H., Itoiz, J., and Del
Castillo, E. B. (1954). Endemic Goitre. Harvard University Press, Cambridge, Mass.

Vilkki, P. (1956). Ann. Acad. Sci. fenn. A 11, 71, 7.

Vought, R. L., and London, W. T. (1964). Amer. f. clin. Nutr., 14, 186. 1218 .

Wayne, E. J., Koutras, D. A., and Alexander, W. D. (1964). Clinical Aspects of Iodine Metabolism. Blackwell, Oxford.

\title{
Total Correction of Tetralogy of Fallot in Young Children
}

\author{
I. K. R. MCMILLAN,* M.B., B.CHIR., F.R.C.S. ; A. M. JOHNSON,† M.D., M.R.C.P.; E. S. MACHELL, F F.F.A. R.C.S.
}

Brit. med. F., 1965, 1, 348-350

The introduction of a technique for performing total correction of the tetralogy of Fallot under cardiopulmonary by-pass was reported by Lillehei et al. (1955).

In spite of successes in children under 5 years reported by Lillehei et al., most centres have avoided performing total correction in the group under 5 owing to the high operative mortality.

In our initial experience in this unit we did not attempt total correction in children weighing less than $15 \mathrm{~kg}$., but with improved and modified techniques using deep hypothermia we have been able to reduce the lower weight limit. In this paper we report the results in 14 small children weighing between 7 and $17 \mathrm{~kg}$. and aged 10 months to 4 years 7 months (Table I). During the same period of time 34 children aged up to 5 years were seen with the tetralogy of Fallot. In two infants a Blalock operation was performed and the other 18 children remain under observation. It must be emphasized that in all of the 14 cases totally corrected the symptoms were severe (Table II) and it was thought that the child would not survive without surgical relief of one or other type.

\section{Method}

With the small hearts of these patients the driest possible operative field was required, and accordingly the principle of circulatory arrest with deep hypothermia was employed in most cases. The principle is the same as that described by Drew et al. (1959), but an oxygenator was used with the standard heart-lung circuit and not the lungs as in his method.

The patients were anaesthetized with nitrous oxide and curare after induction with cyclopropane and oxygen. The chest was opened by median sternotomy and at the same time the left femoral artery and left saphenous vein were prepared.

Arterial pressure was monitored through a catheter in a radial artery or by a side arm from the femoral arterial cannula

\footnotetext{
* Consultant Thoracic Surgeon, Wessex Cardiac and Thoracic Centre, Southampton Chest Hospital

t Consultant Cardiologist, Wessex Cardiac and Thoracic Centre, Southampton Chest Hospital

$\ddagger$ Consultant Anaesthetist, Southampton Chest Hospital.
}

if a sphygmomanometric reading was not easily obtainable. Superior and inferior vena caval pressures were also monitored, together with the electrocardiogram and the electroencephalogram.

The pericardium was opened longitudinally and tapes were passed round the superior and inferior venae cavae and ascending aorta. At this stage the right atrium was explored and the presence of a patent foramen ovale was confirmed or excluded. The patient was then heparinized and the venous cannulae were inserted into the venae cavae. These cannulae were joined by a Y-tube to a venous line, draining by gravity into the pump-oxygenator. In some cases a single metal Drew cannula was inserted into the right atrium. The oxygenator used was the Raison (1963) infant modification of the standard Melrose (1959) N.E.P. machine. The arterial side was connected through a filter and heat exchanger to the left femoral artery cannula in the usual way. Partial perfusion was then instituted and the temperature slowly but steadily reduced, taking from 30 to 60 minutes according to the size of the patient. By monitoring muscle, rectal, nasopharyngeal, and oesophageal temperatures any excessive blood-tissue temperature gradients were avoided.

\begin{tabular}{|c|c|c|c|c|c|}
\hline \multirow{2}{*}{$\begin{array}{l}\text { Case } \\
\text { No. }\end{array}$} & \multicolumn{2}{|c|}{ Age } & \multirow{2}{*}{ Operation Date } & \multirow{2}{*}{ Result } & \multirow{2}{*}{$\begin{array}{l}\text { Follow-up } \\
\text { (Months) }\end{array}$} \\
\hline & Years & Months & & & \\
\hline $\begin{array}{r}1 \\
2 \\
3 \\
4 \\
5 \\
6 \\
7 \\
8 \\
9 \\
10 \\
11 \\
12 \\
13 \\
14\end{array}$ & $\begin{array}{l}\overline{4} \\
2 \\
2 \\
2 \\
1 \\
2 \\
4 \\
3 \\
3 \\
3 \\
1 \\
4 \\
4\end{array}$ & $\begin{array}{r}10 \\
0 \\
3 \\
3 \\
0 \\
4 \\
11 \\
0 \\
6 \\
2 \\
3 \\
6 \\
7 \\
6\end{array}$ & $\begin{array}{l}\text { March } 1962 \\
\text { July } 1962 \\
\text { Sept. } 1962 \\
\text { Oct. } 1962 \\
\text { Nov. } 1962 \\
\text { Jan. } 1963 \\
\text { March } 1963 \\
\text { July } 1963 \\
\text { Dec. } 1963 \\
\text { Jan. } 1964 \\
\text { Feb. } 1964 \\
\text { March } 1964 \\
\text { May } 1964 \\
\text { June } 1964\end{array}$ & $\begin{array}{l}\text { Good } \\
\text { ", } \\
\text { ", } \\
\text { Improved } \\
\text { Good } \\
\text { Fair } \\
\text { Dead } \\
\text { Good } \\
\text { Dead } \\
\text { Good } \\
\text { ", }\end{array}$ & $\begin{array}{l}27 \\
24 \\
21 \\
20 \\
19 \\
17 \\
15 \\
11 \\
= \\
\frac{5}{2} \\
1 \frac{1}{2}\end{array}$ \\
\hline
\end{tabular}

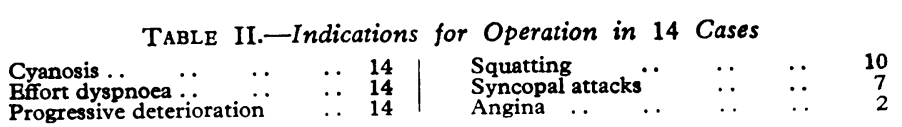

